\title{
INWENTARZ REALNY ŚREDNIOWIECZNYCH DOKUMENTÓW PERGAMINOWYCH I PIECZECI Z ZESPOLU MONASTICA PRZECHOWYWANYCH W ARCHIWUM AKT DAWNYCH DIECEZJI TORUŃSKIEJ W TORUNIU
}

Diecezja toruńska została powołana do istnienia 25 III 1992 r. na mocy bulli Totus Tuus Poloniae Populus wydanej przez papieża Jana Pawła II. Weszła ona w skład metropolii gdańskiej, a jej terytorium ograniczyło się właściwie do trzynastowiecznych granic diecezji chełmińskiej. Została wszak utworzona z terytoriów, które wcześniej wchodziły w jej skład oraz z niewielkiego fragmentu archidiecezji gnieźnieńskiej. Począwszy od 1992 r. organizowano instytucje kościelne, które miały służyć potrzebom nowej diecezji. Dopiero po prawie dziesięciu latach, 24 VI 2001 r., ordynariusz diecezji toruńskiej bp Andrzej Suski powołał do istnienia Archiwum Akt Dawnych Diecezji Toruńskiej, którego siedziba mieści się w gmachu Wyższego Seminarium Duchownego w Toruniu. Z chwilą erygowania archiwum zainicjowano prace mające na celu przechowywanie, porządkowanie i katalogowanie archiwaliów, które napływały z archiwów parafialnych. Znaczną część zgromadzonych archiwaliów stanowią księgi metrykalne $\mathrm{z}$ obszaru dzisiejszej diecezji ${ }^{1}$. Ponadto na zasób archiwum składają się, m.in. takie zespoły, jak: akta parafii katedralnej w Toruniu, akta benedyktynek toruńskich, akta parafii w Brzoziu Lubawskim, akta parafii w Lubawie, akta parafii farnej w Wąbrzeźnie, akta parafii w Nowym Mieście Lubawskim, akta dekanatu lubawskiego czy księgi ławnicze golubskie (z lat 1570-1775)².

* Łukasz Włodarski - mgr historii, doktorant w Instytucie Historii i Archiwistyki UMK, e-mail: wlodarski24@gmail.com

${ }^{1}$ Diecezja toruńska 2012. Struktura i duchowieństwo, red. J.K. Kalinowski, przy współpracy W.K. Miszewskiego, A.J. Piontkowskiego, Toruń 2012, s. 45; Archiwum Akt Dawnych Diecezji Toruńskiej http://www.archiwum.diecezja.torun.pl/historia.html (dostęp: 26.10.2015). Warto nadmienić, że w 2002 r. przejęto z Centralnego Archiwum Biskupiego w Ratyzbonie (Bischöfliche Zentralarchiv Regensburg ) 660 jednostek archiwalnych (metrykalia).

${ }^{2}$ Archiwum Akt Dawnych Diecezji Toruńskiej http://www.archiwum.diecezja.torun.pl/historia. html (dostęp: 26.10.2015). 
Niniejszy inwentarz ma charakter realny, czyli uwzględnia rzeczywisty stan posiadania i obejmuje swym zakresem dokumentację aktową oraz odciski pieczętne wytworzone $\mathrm{w}$ wiekach średnich (do końca $\mathrm{XV} \mathrm{w}$.). W tym miejscu należy zwrócić uwagę, iż co prawda nauka dysponuje już inwentarzem idealnym (zawierającym w większości dokumenty, które nie stanowią zasobu toruńskiego archiwum) pióra Jolanty $\mathrm{Kurek}^{3}$, jednak nie uwzględniał on w ogóle materiału sfragistycznego. W związku z czym nadrzędnym celem niniejszej publikacji staje się edycja pieczęci znajdujących się we wspomnianym archiwum. Ponadto uzasadnienia wymagają ramy chronologiczne uwzględnione w niniejszej pracy. Ograniczenie się z naszej strony do wieków średnich związane jest przede wszystkim ze znaczną objętością materiału źródłowego wytworzonego od XVI do XVIII w., a w zasadzie ze słabym stanem jego opracowania i uporządkowania $\mathrm{w}$ interesującej nas instytucji. Na tym tle dokumenty średniowieczne stanowią stosunkowo szczupły zbiór umożliwiający jego kompletne zestawienie. Niniejszy inwentarz ma również pełnić rolę pomocy informacyjno-ewidencyjnej oraz ułatwić badaczom przeprowadzenie ewentualnej kwerendy w zasobie Archiwum Akt Dawnych Diecezji Toruńskiej. Spis zawiera co prawda tylko siedem dokumentów pergaminowych niemniej są to najcenniejsze zabytki materialne przechowywane aktualnie w tej instytucji. Wchodzą one w skład zespołu Monastica, seria Benedyktynki Toruń, podseria diplomata (oznaczenie w inwentarzu MAD). Pierwotnie stanowiły one fragment zasobu archiwum znajdującego się przy parafii pw. św. Jakuba Apostoła w Toruniu (dawniej w Nowym Mieście Toruniu) przejętego (tylko częściowo) przez Archiwum Akt Dawnych Diecezji Toruńskiej.

Stworzony przez J. Kurek inwentarz realny zawierał następujące elementy: miejsce i datę wystawienia dokumentu, regest, opis fizyczny dokumentu (status dyplomu, stan zachowania, język dokumentu oraz wymiary ${ }^{4}$ ), aktualną sygnaturę archiwalną oraz uwagi, w których uwzględniono m.in. ewentualne edycje, regesty bądź transumpty. Ze względu na podanie przez J. Kurek w swoim inwentarzu miejsc publikacji (druku, regestu) niniejszych dokumentów, autor świadomie rezygnuje z przytaczania starszych wydań (poza wskazaniem edycji w Urkundenbuch des Bisthums $\mathrm{Culm}^{5}$ ), wskazując wskazując jednocześnie odpowiednie miejsce w inwentarzu idealnym. Jak już wspomniano brak jakichkolwiek odniesień J. Kurek do materiału sfragistycznego sprawia, iż głównym celem niniejszej publikacji staje się jego edycja. Ponadto z naszej strony opis jednostek został uzupełniony o podanie obecnej sygnatury w Archiwum Akt Dawnych Diecezji Toruńskiej oraz poprawne wymiary dokumentów.

${ }^{3}$ J. Kurek, Inwentarz zespotu akt cysterek-benedyktynek toruńskich z lat 1311-1833, (dalej: Inwentarz) „Archiwa, Biblioteki i Muzea Kościelne”, 86 (2006) s. 189-285. Wszystkie dokumenty prezentowane $\mathrm{w}$ naszym inwentarzu posiadają sygnaturę dawną $\mathrm{z}$ archiwum mieszczącego się przy kościele pw. św. Jakuba Apostoła w Toruniu.

${ }^{4}$ Zważywszy na fakt, że J. Kurek nie zawsze podaje wymiary dokumentów lub w przypadku gdy to czyni są one niepoprawne, w odpowiednich miejscach czynimy odpowiednie adnotacje w przypisach.

${ }^{5}$ Urkundenbuch des Bisthums Culm (dalej: UBC) Bd. 1, bearbeitet C.P Woelky, Danzig 1885. 
Stosowany tutaj termin cysterki-benedyktynki określa pewne specyficzne wspólnoty cysterek obediencji biskupiej, które nie były inkorporowane do Sacer Ordo Cisterciensis lub nie znajdowały się pod rzeczywistą opieką zakonną. W związku z powyższym w takich wspólnotach monastycznych zaczęły pojawiać się pewne odstępstwa od reguły cysterskiej. Następowało niejako „zmieszanie się" cysterskich regulacji z zasadami życia zakonnego benedyktynek. Skutkiem takich praktyk był fakt odejścia cysterek od pierwotnych konstytucji zakonnych oraz stworzenie specyficznej formy monastycyzmu nazywanej dziś cysterkami-benedyktynkami. Ponadto odbicie sytuacji wewnętrznej takiego zgromadzenia widoczne było chociażby w naprzemiennym nazywaniu się cysterkami lub benedyktynkami ${ }^{6}$. Toruński klasztor cysterek-benedyktynek został ufundowany przez Krzyżaków w 1311 r. przy kościele Świętego Ducha. Od samego początku funkcjonował jako wspólnota cysterek-benedyktynek obediencji biskupiej, a ściślej biskupów chełmińskich, zarządzana przez prepozyta, który jednocześnie należał do zakonu krzyżackiego. Jej życie zakonne regulowały dwa dokumenty - Reguła św. Benedykta z Nursji oraz konstytucja cysterska7. W 1327 r. wielki mistrz Werner von Orseln dokonał translokacji toruńskiego klasztoru cysterek-benedyktynek z siedziby przy szpitalu pw. Św. Ducha do siedziby przy kościele pw. Sw. Krzyża (nr 1). Z jego nadania w 1330 r. zakonnice otrzymały prawo patronatu nad kościołem parafialnym i kaplicą pw. Panny Marii w Szynwałdzie (nr 2). Z kolei Teodoryk z Altenburga przyznał zakonnicom prawo patronatu nad kościołem pw. św. Jakuba w Toruniu, które potwierdzone zostało przez jego następcę Ludolfa Königa (nr 3), a w 1415 r. wielki mistrz Michał Küchmeister przyłączył klasztor toruńskich cysterek-benedyktynek do szpitala pw. Św. Ducha (nr 6). Kres działalności toruńskiego klasztoru przyniósł rok 1833, kiedy to nastąpiła jego kasata.

Przechodząc do krótkiego opisu pozycji katalogowych dostrzegamy, że cztery dokumenty zamieszczone $\mathrm{w}$ inwentarzu zostały wystawione przez kancelarię wielkich mistrzów Zakonu Krzyżackiego (nr 1, 2, 3, 6). Pozostałe pojedyncze dokumenty pochodzą z Nowego Miasta Torunia (nr 4), klasztoru cysterek-benedyktynek w Królewcu (nr 5) oraz prepozyta toruńskiego klasztoru cysterek-benedyktynek Jana Tanennberga (nr 7). W czterech przypadkach dokumenty wystawiono w Toruniu (nr 1, 4, 6, 7), dwukrotnie w Malborku (nr 2, 3), a raz w Królewcu (nr 5). Cztery dokumenty (oraz trzy odciski pieczęci) pochodzą z XIV w., a pozostałe trzy dyplomy (i dwie pieczęcie) z XV w. Sześć dokumentów zachowało się w oryginale, natomiast jeden w piętnastowiecznej kopii (nr 2). Dyplomy w czterech przypadkach zostały spisane w języku niemieckim ( $\mathrm{nr} 2,4$, 6, 7), w pozostałych trzech po łacinie.

Odciski pieczętne przetrwały przy pięciu dyplomach (nr 1, 4, 5, 6, 7). Dwa $\mathrm{z}$ nich to pieczęć urzędowa, przechodnia wielkiego mistrza pochodzące $\mathrm{z}$ tego samego typariusza (nr 1,6) oraz po jednej Nowego Miasta Torunia (nr 4), klasztoru benedyktynek w Królewcu (nr 5) oraz prepozyta Jana Tanenberga (nr 7). Spośród

${ }^{6}$ Inwentarz, s. 189-190, przyp. 1.

7 Tamże, s. 190-191; P. Oliński, Fundacje mieszczańskie w miastach pruskich $w$ okresie średniowiecza i na progu czasów nowożytnych (Chetmno, Toruń, Elbląg, Gdańsk, Królewiec, Braniewo), Torun 2008, s. 520-521. 
pięciu zachowanych odcisków pieczętnych trzy są okrągłe $(\mathrm{nr} 1,4,6)$ zaś dwa pozostałe w kształcie mandreoli (nr, 5, 7). Zdecydowana większość z nich została odciśnięta w wosku koloru czarnego $(\mathrm{nr} 1,4,6)$, a po jednej w wosku czerwonym (nr 5) i ciemnozielonym (nr 7). Analizując odciski pod kątem wyobrażenia napieczętnego, cztery z nich przedstawiają formę dewocyjną (nr 1, 5, 6, 7), z kolei jedna wyobrażenie architektoniczne (nr 4). Legenda pieczęci w czterech przypadkach została zapisana majuskułą gotycką ( $\mathrm{nr} 1,4,5,6)$, zaś raz przyjęła formę minuskulną (nr 7). Pieczęcie czterokrotnie zawieszane były na paskach pergaminowych (nr 4, 5, 6, 7), a tylko raz na sznurze jedwabnym (nr 1) ${ }^{8}$.

Podstawę opisu poszczególnych jednostek archiwalnych stanowi formularz składający się z następujących elementów:

Numer regestu

1. Miejsce i data wystawienia dokumentu według dzisiejszej rachuby czasu (wersalikiem) oraz lekcji oryginału (kursywą w nawiasie).

2. Regest dokumentu w języku polskim.

3. Obecna sygnatura.

4. Podstawowy opis fizyczny dokumentu, na który składają się: status źródła (oryginał, kopia), materiał pisarski, wymiary dokumentu (podane w milimetrach).

5. Ocena stanu zachowania dokumentu.

6. Język dokumentu.

7. Edycja oraz miejsce w inwentarzu idealnym stworzonym przez J. Kurek.

8. Opis odcisku pieczętnego uwzględniający wymiary pieczęci (podane w milimetrach), kształt pieczęci, odczyt legendy, rodzaj pisma legendy, rodzaj osłony pieczęci, rodzaj mocowania pieczęci, kolor wosku, opis pieczęci, ważniejsze (wybrane) publikacje, ewentualne uwagi.

${ }^{8} \mathrm{~W}$ tym miejscu należy wspomnieć, że przy dokumencie nr 3 widoczne są ślady uwierzytelnienia go pieczęcią. Kształt i rozmiar otworów pozwalają domniemywać, iż był to sznur jedwabny.

${ }^{9}$ Przy opisie pieczęci stosujemy schemat informacyjno-ewidencyjny, który został zaczerpnięty z publikacji: M. Hlebionek, Katalog pieczęci przy dokumentach samoistnych w zasobie Archiwum Państwowego w Bydgoszczy, Warszawa 2012. Z kolei inskrypcje napieczętne zostały opisane zgodnie z zasadami wydawniczymi zawartymi w instrukcji Marcina Hlebionka: Zasady Transkrypcji inskrypcji napieczętnych http://adacta.archiwa.net/file/sceaux/transceaux.pdf (dostęp: 26.02.2016). 


\section{INWENTARZ REALNY}

\section{1}

1. Torun, 4 X 1327 r. (Thorun, in die sancti Francisci)

2. Wielki mistrz Werner von Orseln (Wernherus de Orsela $)^{10}$ dokonuje translokacji toruńskiego klasztoru cysterek-benedyktynek z siedziby przy szpitalu Św. Ducha do siedziby przy kościele Św. Krzyża.

3. Sygnatura: MAD 001.

4. Oryginał, pergamin, wymiary: $391 \times 257+46^{11}$.

5. Stan zachowania: dobry.

6. Język: łaciński.

7. Druk: UBC, Bd. I, nr 219; Regest: Inwentarz, s. 196, nr 3.

8. Pieczęć:

Wymiary pieczęci: ok. Ø $48 \mathrm{~mm}$

Kształt pieczęci: okrągła.

Pismo: majuskuła gotycka.

Odcisk:

Materiał osłony: pierwotnie, zapewne, wosk. Obecnie osłona wtórna - wosk koloru naturalnego oraz metalowa puszka założona prawdopodobnie w XIX w.

Mocowanie odcisku/osłony: sznur jedwabny.

Materiał odcisku: czarny wosk.

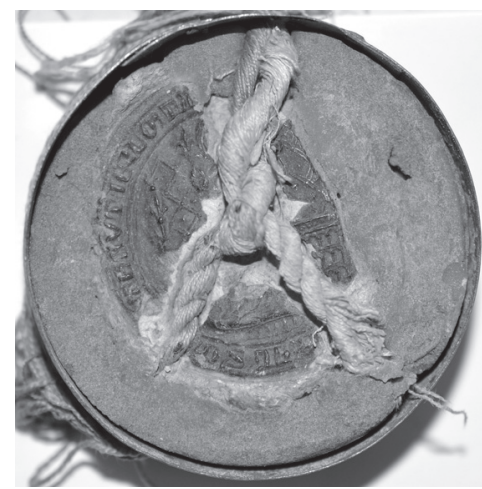

Legenda pieczęci: [+ S MAG(ist)RI GENERAL(is) HOSPIT]AL(is) S(ancte) $\mathrm{M}$ [ARIE] THEVT(onicorum) $\mathrm{I}(e) \mathrm{R}($ oso $) \mathrm{L}(o) \mathrm{M}(i) \mathrm{TA}[\mathrm{N}(i)]$

Opis pieczęci: W polu pieczęci (zachowanego fragmentarycznie w trzech częściach), oddzielonym od legendy linią z perełek, fragmenty skrzyniowego, flankowanego tronu. Nad faldistorium berło o zakończeniu w kształcie lilii. Ponadto widać fragment nimbu. U podstawy tronu widoczne są fragmenty dolnej części szat. Tło pola pieczęci wypełnia ukośna szachownica, pola jej rombów przyozdobione są umieszczonymi centralnie małymi, równoramiennymi krzyżykami. Na zewnątrz pola pieczęci, po zewnętrznej stronie napisu, perełkowe okolenie.

PUBLIKACJE:

W. Nöbel, Michael Küchmeister. Hochmeister des Deutschen Ordens 1414-1422 (Quellen und Studien zur Geschichte des Deutschen Ordens t. 5), Marburg 1968, s. X; H. G. Boehm, Siegel des

${ }^{10}$ Werner von Orseln - wielki mistrz zakonu krzyżackiego w latach 1324-1330. Wcześniej pełnił m.in. urząd wielkiego komtura i komtura Malborka. Zob. więcej K. Conrad, Werner von Orseln (6 VII 1324 - 18 XI 1330), w: Die Hochmeister des Deutschen Ordens 1190-1994, herausgegeben v. U. Arnold (Quellen und Studien zur Geschichte des Deutschen Ordens, Bd. 40), Marburg 1998, s. $60-65$.

${ }^{11}$ Inwentarz, nr 3 nie podaje wymiarów. 
Deutschen Ordens von Akkon bis Mergentheim (Wissenschaftliche Vereinigung für den Deutschen Orden. Schriftenreihe), Bad Mergentheim 2002, s. 3.

UWAGI: Pieczęć urzędowa, przechodnia. Pieczęć pokruszona, wymaga konserwacji. Porównaj pieczęć przy dokumencie nr 6.

1. Malbork, $15 \mathrm{~V} 1330$ r. (Marienburg, Idus Maii, indiccione terciadecima)

2. Wielki mistrz Werner von Orseln (Wernherus de Orzela) ${ }^{12}$ nadaje toruńskiemu klasztorowi cysterek-benedyktynek prawo patronatu nad kościołem parafialnym i kaplicą pw. Panny Marii w Szynwałdzie.

3. Sygnatura: MAD 002.

4. Kopia z XV w., pergamin, wymiary: $291 \times 274^{13}$.

5. Stan zachowania: dobry.

6. Język: niemiecki (tłumaczenie z łaciny ${ }^{14}$ ).

7. Druk: UBC, Bd. I, nr 229; Regest: Inwentarz, nr 6.

8. Pieczęć: brak ${ }^{15}$.

1. Malbork, 6 I 1345 r. (Marienburg, in Epiphania Domini)

2. Wielki mistrz Ludolf König (Ludolfus Konyng) ${ }^{16}$ potwierdza toruńskiemu klasztorowi cysterek-benedyktynek prawa patronatu nad kościołem parafialnym pw. św. Jakuba w Nowym Mieście Toruniu nadane przez Teodoryka z Altenburgu (Theodericus de Aldenburg) ${ }^{17}$.

3. Sygnatura: MAD 003.

4. Oryginał, pergamin, wymiary: $369 \times 291+37^{18}$.

5. Stan zachowania: dobry.

6. Język: łaciński.

7. Druk: UBC, Bd. I, nr 281; Regest: Inwentarz, s.198-199, nr 12.

8. Pieczęć: brak.

UWAGI: Dwa otwory po sznurach od pieczęci.

\footnotetext{
${ }^{12}$ Por. przyp. 10.

${ }^{13}$ Inwentarz, nr 6 podaje błędne wymiary: $280 \times 285 \mathrm{~mm}$.

${ }^{14}$ Por. Inwentarz, nr 5 gdzie oryginał w j. łacińskim.

${ }^{15}$ Brak jakichkolwiek śladów przywieszenia pieczęci.

${ }^{16}$ Ludolf König wielki mistrz zakonu krzyżackiego w latach 1342-1345. Ponadto pełnił wcześniej urzędy wielkiego podskarbiego oraz wielkiego komtura. Zob. więcej K. Conrad, Ludolf König (6 I 1342 - 14 IX 1345), w: Die Hochmeister, s. 78-79.

${ }^{17}$ Teodoryk z Altenburgu wielki mistrz zakonu krzyżackiego w latach 1335-1341. Wcześniej pełnił urząd wielkiego marszałka. Zob. więcej K. Conrad, Dietrich von Altenburg (3 V $1335-6$ X 1341), w: Die Hochmeister, s. 70-73.

${ }^{18}$ Inwentarz, nr 12 nie podaje wymiarów dokumentu.
} 
1. Torun [?], 1359 r. [brak daty dziennej]

2. Dwaj krewni [a zarazem rajcy Nowego Miasta Torunia], Jan Aldeweise (Johannes Aldewise ${ }^{19}$ i Jan Jungeweise (Johannes Jvngewise) ${ }^{20}$, fundują kaplicę (obowiązek modlitewny w kaplicy) w kościele pw. św. Jakuba w Nowym Mieście Toruniu.

3. Sygnatura: MAD 004.

4. Oryginal, pergamin, wymiary: $315 \times 214+55^{21}$.

5. Stan zachowania: dobry.

6. Język: niemiecki.

7. Druk: UBC, Bd. I, nr 303; Regest: Inwentarz, s. 200, nr 19.

8. Pieczęć:

Wymiary pieczęci: Ø $60 \mathrm{~mm}$

Kształt pieczęci: okrągła

Pismo: majuskuła gotycka

Odcisk:

Materiał osłony: brak

Mocowanie odcisku/osłony: pasek pergaminowy

Materiat odcisku: czarny wosk

Legenda pieczęci: + SIG[IL]LVM NO[VE

CIVIT]ATIS $\cdot$ TO[R]VN

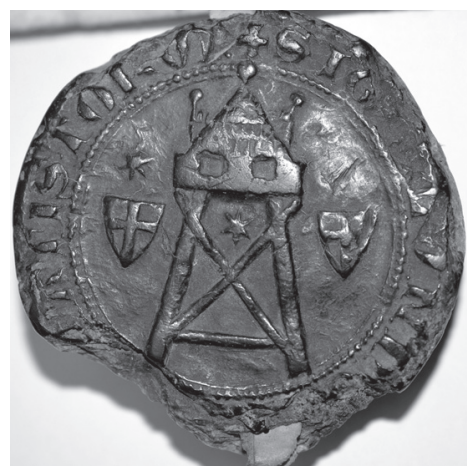

Opis pieczęci: W polu pieczęci, oddzielonym od legendy dwiema liniami, jedną z kropek, a drugą ciągłą, strażnica wojskowa z belek ze spiczastym dachem pokrytym gontem i zwieńczony gałką. Po bokach dachu dwa erkery, a u jego podstaw blanki. Po bokach strażnicy dwie tarcze gotyckie $\mathrm{z}$ herbem Zakonu Krzyżackiego. Nad tarczami oraz pomiędzy belkami konstrukcji trzy sześciopromienne gwiazdy. Na zewnątrz pola pieczęci, po zewnętrznej stronie napisu, okolenie w kształcie perełek.

\section{PUBLIKACJE:}

M. Gumowski, Pieczęcie i herby miast pomorskich, Toruń 1939, s. 161; tenże, Najstarsze pieczęcie miast polskich XIII i XIV w., Torun 1960, nr 466, s. 226; tablica XXXVI; K. Ciesielska, Herb i pieczęcie miasta Torunia, Toruń 1982, s. 17.

UWAGI: Przywieszenie pieczęcie miejskiej pod dokumentem było związane z faktem, iż obaj fundatorzy zasiadali w radzie Nowego Miasta Torunia.

${ }^{19}$ Jan Aldeweise (Jan Sapiens) rajca Nowego Miasta Torunia, który zasiadał w radzie co najmniej w latach 1346-1359. Wcześniej, bo w 1328 r. był sędzią miejskim. Zob. więcej R. Czaja, Urzędnicy miejscy Torunia do roku 1454, Toruń 1999, s. 152-153; Oliński, Fundacje, s. 214.

${ }^{20}$ Jan Jungeweise rajca Nowego Miasta Torunia zasiadający w radzie w latach 1347-1359. Zob. więcej Czaja, Urzędnicy miejscy, s. 149, 151-152; Oliński, Fundacje, s. 214.

${ }^{21}$ Inwentarz, nr 19 podaje błędne wymiary (nie uwzględniające zakładki): 220×315 mm. 
1. Królewiec [?], 27 V 1382 r. (VI Kalendas Juni)

2. Benedyktynki z Królewca proszą konwent toruński o zawarcie wspólnoty modlitewnej.

3. Sygnatura: MAD 004.

4. Oryginał, pergamin, wymiary: $247 \times 84^{22}$.

5. Stan zachowania: dobry.

6. Język: łaciński.

7. Druk: UBC, Bd. I, nr 361; Regest: Inwentarz, s. 202, nr 25.

8. Pieczęć:

Wymiary pieczęci: $57 \times 36 \mathrm{~mm}$

Kształt pieczęci: ostroowalna

Pismo: majuskuła gotycka

Odcisk:

Materiał osłony: $\mathrm{z}$ wosku

Mocowanie odcisku/osłony: pasek pergaminowy

Materiał odcisku: czerwony wosk

Legenda pieczęci: + S' SANCTIMONIALIU[M] IN KUNGISBERCK

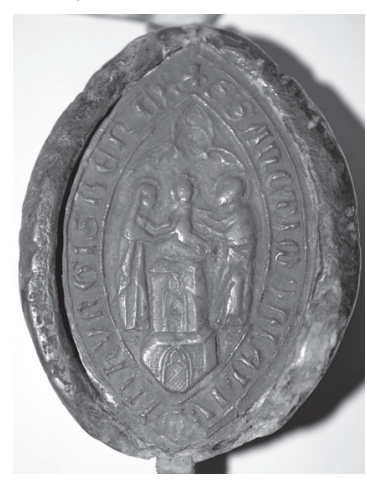

Opis pieczęci: $\mathrm{W}$ polu pieczęci, oddzielonym od legendy ciągła linią, scena Ofiarowania Pańskiego w świątyni. Po prawej stronie (heraldycznej) świątyni stojąca postać Najświętszej Marii Panny w obszernych szatach z nibem wokół głowy, z lewej osoba św. Józefa z nimbem. Maryja, dzierżąca w swych dłoniach Dzieciątko Jezus (również z nimbem wokół głowy) przekazuje je, nad świątynią, którą przedstawia gotycki kościół św. Józefowi. U góry pieczęci widoczny jest trójłuk gotycki. Na zewnątrz pola pieczęci, po zewnętrznej stronie napisu, okolenie w kształcie ciągłej linii.

PUBLIKACJE: UBC, Bd. I, nr 361 (opis). B. Engel, Mittelalterlichen Siegel der Fürsten der Geistlichkeit und des Polnischen Adels im Thorner Rathsarchive, Danzig 1902, s. 8; Taf. II, nr 25.

UWAGI: Na zewnętrznej stronie miseczki woskowej znajdują się odciski trzech koniuszków palców, stanowiące dodatkowe zabezpieczenie pieczęci.

${ }^{22}$ Inwentarz, nr 25 podaje błędne wymiary $250 \times 247 \mathrm{~mm}$. 
1. Torun, 12 IX 1415 r. (Thorun, am nehesten donrstage vor Crucis exaltacionis)

2. Wielki mistrz Michał Küchmeister (Michael Kochmeister) ${ }^{23}$ łączy dobra klasztorne toruńskich cysterek - benedyktynek z dobrami szpitala pw. Św. Ducha.

3. Sygnatura: MAD 006.

4. Oryginal, pergamin, wymiary: $532 \times 472+88^{24}$.

5. Stan zachowania: dobry.

6. Język: niemiecki.

7. Druk: UBC, Bd. I, nr 490; Regest: Inwentarz, s. 209-210, nr 51.

8. Pieczęć:

Wymiary pieczęci: Ø 48,5 mm

Kształt pieczęci: okrągła

Pismo: majuskuła gotycka

Odcisk:

Materiał osłony: $\mathrm{z}$ wosku oraz metalowa puszka założona prawdopodobnie w XIX wieku

Mocowanie odcisku/osłony: pasek pergaminowy

Materiał odcisku: czarny wosk

Legenda pieczęci: + S MAG(ist)RI GENERAL(is) HOSPITAL(is) S(ancte) MARIE THEVT(onicorum) $\mathrm{I}(e) \mathrm{R}($ oso $) \mathrm{L}(o)$ $\operatorname{M}(i) \operatorname{TAN}(i)$

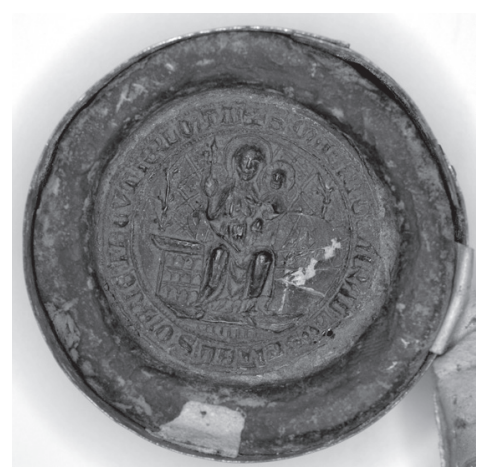

Opis pieczęci: W polu pieczęci, oddzielonym od legendy linią z perełek, Najświętsza Maria Panna zasiadająca na skrzyniowym, flankowanym pinaklami, tronie. Odziana jest w obszerne szaty. Jej głowę wieńczy korona, a wokół niej widoczna jest promienista aureola. W prawej dłoni Maryja dzierży berło, zakończone kwiatem lilii, zaś lewą dłonią podtrzymuje Dzieciątko Jezus zasiadające na jej kolanach. Dzieciątko ma podniesioną prawicę w geście benedykcji, a lewą dłoń położoną na udzie. Wokół Jego głowy widnieje nimb. Tło pola pieczęci wypełnia ukośna szachownica, pola jej rombów przyozdobione są umieszczonymi centralnie małymi, równoramiennymi krzyżykami. Na zewnątrz pola pieczęci, po zewnętrznej stronie napisu, perełkowe okolenie.

PUBLIKACJE: Por. nr 1.

${ }^{23}$ Michał Küchmeister wielki mistrz zakonu krzyżackiego w latach 1414-1422. Począwszy od końca XIV w. pełnił szereg urzędów w państwie krzyżackim, będąc kolejno komturem na zamku w Rynie, prokuratorem kętrzyńskim, szafarzem elbląskim, wielkim szafarzem oraz wielkim marszałkiem. Zob. więcej W. Nöbel, Michael Küchmeister. Hochmeister des Deutschen Ordens 14141422 (Quellen und Studien zur Geschichte des Deutschen Ordens, Bd. 5), Marburg 1968; B. Jähnig, Michael Küchmeister (9 I 1414 - 10 III 1422), w: Die Hochmeister, s. 119-122.

${ }^{24}$ Inwentarz, $\mathrm{nr} 51$ podaje błędne wymiary: $475 \times 545+90 \mathrm{~mm}$. 
1. Toruń, 18 XI 1431 r. (Thorun, am Sontage noch Martini)

2. Jan Tannenberg (Johannes Tannenberg) ${ }^{25}$, prepozyt toruńskiego klasztoru cysterek - benedyktynek, sprzedaje za zgodą przeoryszy, jedną włókę ziemi lub łąki w Młyńcu niejakiemu Mikołajowi Steffanssonowi (Niclos Steffans) ${ }^{26}$.

3. Sygnatura: MAD 007.

4. Oryginał, pergamin, wymiary: $252 \times 155+22^{27}$.

5. Stan zachowania: dobry.

6. Język: niemiecki.

7. Druk: UBC, Bd. I, nr 560; Regest: Inwentarz, s. 212, nr 62.

8. Pieczęć:

Wymiary pieczęci: $46 \times 26,5 \mathrm{~mm}$

Kształt pieczęci: ostroowalna

Pismo: minuskuła gotycka

Odcisk:

Materiał osłony: $\mathrm{z}$ wosku

Mocowanie odcisku/osłony: pasek pergaminowy

Materiał odcisku: ciemnozielony wosk

Legenda pieczęci: $+\mathrm{S}$ (gwiazdka) $\mathrm{P}(r e) \mathrm{PO}(s) \mathrm{ITI}$

: SANCTI : MONIALIUM : IN : THORN

(pięciolistny kwiat) :::::

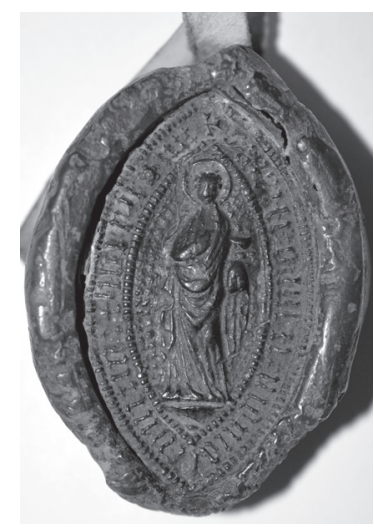

Opis pieczęci: W polu pieczęci, oddzielonym od legendy linią z perełek, stojąca postać (św. Benedykta?) w obszernych szatach, z prawicą wzniesioną w geście błogosławieństwa, w lewej dzierżąca kielich (?). Jej głowę otacza promienisty nimb. Tło pola pieczęci wypełniają czteropromienne gwiazdki w postaci guzków. $\mathrm{Na}$ zewnątrz pola pieczęci, po zewnętrznej stronie napisu, okolenie w kształcie perełek.

PUBLIKACJE: UBC, Bd. I, nr 560 (opis); B. Engel, Mittelalterlichen Siegel, s. 8; Taf. III, nr 32.

Słowa kluczowe: średniowiecze, dokumenty pergaminowe, pieczęcie, inwentarz realny, archiwum diecezjalne, Toruń, benedyktynki-cysterki.

${ }^{25}$ Jan Tannenberg w latach 1411-1431 pełnił funkcję prepozyta toruńskich cysterek-benedyktynek. Ponadto posiadał prebendę kanonika kapituły katedralnej w Chełmży. Był również potwierdzony na probostwie kościoła parafialnego w Nowym Mieście Toruniu (do 1429). Zob. więcej R. Krajniak, Torunianie w sktadzie kapituly katedralnej w Chetmży do 1466 roku, „Klio”, 18 (2011) nr 8, s. 34-36.

${ }^{26}$ Bliżej nieznany.

${ }^{27}$ Inwentarz, nr 62 podaje błędne wymiary: $160 \times 255+20 \mathrm{~mm}$. 


\section{BIBLIOGRAFIA}

\section{Źródla}

Archiwum Akt Dawnych Diecezji Toruńskiej w Toruniu, sygn. 001 - 007, Monastica, Benedyktynki Toruń, Diplomata.

Urkundenbuch des Bisthums Culm, Bd. 1, bearbeitet C. P Woelky, Danzig 1885.

\section{Opracowania}

Boehm Hans Georg, Siegel des Deutschen Ordens von Akkon bis Mergentheim, (Wissenschaftliche Vereinigung für den Deutschen Orden. Schriftenreihe.) Bad Mergentheim 2002.

Ciesielska Karola, Herb i pieczęcie miasta Torunia, Toruń 1982.

Conrad Klaus, Dietrich von Altenburg (3 V 1335 - 6 X 1341), w: Die Hochmeister des Deutschen Ordens 1190-1994, herausgegeben U. Arnold (Quellen und Studien zur Geschichte des Deutschen Ordens, t. 40), Marburg 1998, s. 70-73.

Conrad Klaus, Ludolf König (6 I 1342 - 14 IX 1345), w: Die Hochmeister des Deutschen Ordens 1190-1994, herausgegeben U. Arnold (Quellen und Studien zur Geschichte des Deutschen Ordens, t. 40), Marburg 1998, s. 78-79.

Conrad Klaus, Werner von Orseln (6 VII1324 - 18 XI 1330), w: Die Hochmeister des Deutschen Ordens 1190-1994, herausgegeben U. Arnold (Quellen und Studien zur Geschichte des Deutschen Ordens, t. 40), Marburg 1998, s. 60-65.

Czaja Roman, Urzędnicy miejscy Torunia do roku 1454, Toruń 1999.

Diecezja toruńska 2012. Struktura i duchowieństwo, red. J. K. Kalinowski, przy współpracy W. K. Miszewskiego i A. J. Piontkowskiego, Toruń 2012.

Engel Bernhard, Mittelalterlichen Siegel der Fürsten der Geistlichkeit und des Polnischen Adels im Thorner Rathsarchive, Danzig 1902.

Gumowski Marian, Pieczęcie i herby miast pomorskich, Toruń 1939.

Gumowski Marian, Najstarsze pieczęcie miast polskich XIII i XIV w., Toruń 1960.

Hlebionek Marcin, Katalog pieczęci przy dokumentach samoistnych w zasobie Archiwum Państwowego w Bydgoszczy, Warszawa 2012.

Jähnig Bernhart, Michael Küchmeister (9 I 1414 - 10 III 1422), w: Die Hochmeister des Deutschen Ordens 1190-1994, herausgegeben U. Arnold (Quellen und Studien zur Geschichte des Deutschen Ordens, t. 40), Marburg 1998, s. 119-122.

Krajniak Radosław, Torunianie w składzie kapituły katedralnej w Chełmży do 1466 roku, „Klio”, 18 (2011) s. 17-41.

Kurek Jolanta, Inwentarz zespołu akt cysterek-benedyktynek toruńskich z lat 1311- 1833, „Archiwa, Biblioteki i Muzea Kościelne”, 86 (2006) s. 189-285.

Nöbel Wilhelm, Michael Küchmeister. Hochmeister des Deutschen Ordens 1414-1422 (Quellen und Studien zur Geschichte des Deutschen Ordens t. 5), Marburg 1968.

Oliński Piotr, Fundacje mieszczańskie w miastach pruskich w okresie średniowiecza i na progu czasów nowożytnych (Chełmno, Toruń, Elbląg, Gdańsk, Królewiec, Braniewo), Toruń 2008.

\section{Internet}

Zasady transkrypcji inskrypcji napieczętnych, http://adacta.archiwa.net/file/sceaux/transceaux.pdf (dostęp: 26.02.2016)

Archiwum Akt Dawnych Diecezji Toruńskiej, http://www.archiwum.diecezja.torun.pl/historia.html (dostęp: 26.10.2015) 


\title{
THE INVENTORY OF THE MEDIEVAL PARCHMENT DOCUMENTS AND SEALS OF THE MONASTICA COLLECTION STORED IN THE HISTORICAL ARCHIVE OF THE DIOCESE OF TORUŃ IN TORUŃ
}

\begin{abstract}
Summary
The following inventory presents parchment documents and medieval impressions of seals stored in the Historical Archive of the Diocese of Torun. It only includes the archival materials stored in the aforementioned archive. Its task is primarily to fulfil the role of information and aid and to facilitate any archival research. The list published here contains seven parchment documents and five sigils, which are the most valuable part in the collection of this institution. Currently, they form part of the Monastica collection, Benedyktynki Toruń series, Diplomata subseries; initially, they constituted a fragment of the archival collection located at St. James the Apostle Parish in Torun. The description of the individual archival units consist of the following elements: the number of regesta, the place and date of issuing a document, the regesta of a document in Polish, the current reference code, the physical description of a document, the actual condition of a document, previous editions and the description of seal impressions.
\end{abstract}

Keywords: the Middle Ages, parchment documents, seals, inventory, diocesan archive, Toruń, Benedictine-Cistercian Sisters. 